\title{
The Selection of Academic Library Materials, A Literature Survey
}

\begin{abstract}
A survey of the literature of book selection in academic libraries indicates that there has been for more than a half-century a continuing shift from faculty-dominated selection to library-dominated selection. It appears likely that the trend will continue, because of the increased use of subject specialists on library staffs, the growth of the publication industry, the articulation of more selection policy statements, as well as increasingly widespread recognition of selection as part of the librarian's professional responsibility.
\end{abstract}

$\mathrm{T}$ HE PURPOSE of this paper is to survey the professional literature as it pertains to the selection of materials for academic libraries, and especially selection with respect to who chooses titles for a collection and the criteria, guidelines, and tools utilized.

Writing in 1957 concerning the selection policies in fifty-four colleges he had surveyed, Harry Bach, then at San Jose State College, California, neatly divided the usual library acquisition routines into three basic patterns.

If libraries are classified according to the role in the selection of library materials they seem to fall into three categories(1) Self-effacing libraries, (2) Libraries in which materials are selected by the faculty with the aid and advice of the library, and (3) Libraries in which materials are selected by the library with the aid and advice of the faculty.

1. Self-effacing libraries. These .... are characterized by over-reliance on the faculty and a 20th Century version of a 19th Century outlook on book selection. Libraries in this group disclaim almost all responsibility for the development of the collection. [Only 5 of the 54 responding libraries are in this class.]

$\mathrm{Mr}$. Lane is Assistant University Librarian, University of California, San Diego, in La Jolla.
2. Libraries in which materials are selected by the faculty with the aid and advice of the library. . . . Book selection for the university departments is left almost entirely in the hands of the faculty. . . . The librarian and library staff supplement and round out faculty buying in the various fields and select those works which are not specifically needed for the work of particular departments. They also call faculty members' attention to important publications in their field. [There were numerous examples of this in the survey of 54 libraries.]

3. Libraries in which materials are selected by the library with the aid and advice of the faculty. These libraries . . . represent . . . the avant guard of librarianship in the matter of library responsibility in book selection. . . . At Columbia, for instance, according to the annual report of the Director of Libraries, supervising librarians and department heads do the day-to-day selecting of publications for the collections under their immediate control. Although faculty members made recommendations as to items to be pucrhased, the library relies upon its staff members to ... indicate significant publications which shall be acquired. (Six libraries of the 54 surveyed were in this group. $)^{1}$

\footnotetext{
${ }^{1}$ Harry Bach, "Acquisition Policy in the American Academic Library," CRL, XVIII (November, 1957), 446-47.
} 
Historically, American institutions of higher education are adaptations of European models. Colleges, in general, were modeled after English examples. Graduate universities, when they finally began to develop toward the end of the nineteenth century, attempted to imitate German models, for the nineteenth century German universities were thought to be without peer. ${ }^{2}$

As early as 1800 , the library of the University of Goettingen contained nearly two hundred thousand volumes, while at about the same time (1790) the Harvard College library held a mere twelve thousand volumes. ${ }^{3}$ The library of the University of Goettingen, founded 1737 , seems to have been the first modern "research" library in the sense that we now use the term. The first Kurator of the University, Count Gerlach Adolph Von Muenchhausen, was

... . in a very real sense the spiritual father and the planner of the University library. . . . Among his [major principles] were very liberal regulations for use ... regular budgets, scholarly quality, usefulness and up-to-dateness of the collection; and book selection on a planned, regular and international basis. Above all, and perhaps for the first time anywhere, Muenchhausen consciously viewed the library as an indispensable [tool] for the institution's teaching and research, as a part which could fulfill its essential role only by planned growth and regular nourishment. ${ }^{4}$ This was the academic library that served as a goal for the other German institutions of the nineteenth century and ultimately for American colleges when their graduate programs started to develop toward the end of the last century.

The second librarian of that university, Christian Gottlob Heyne (librarian 1764-1812), held, according to Danton,

${ }^{2}$ J. Periam Danton, Book Selection and Collections: A Comparison of German and American University Libraries (New York: Columbia University, 1963), p. $\mathbf{x x}$.

${ }^{3}$ Ibid., p. 14.

1 Ibid., p. 15.
.. . the reins of book selection firmly in his own hands. For years he carried on a staggeringly voluminous correspondence with book dealers and publishers all over the world. 5

Danton shows statistics of the rapid growth of Goettingen University library in the nineteenth century. The other German libraries also grew rapidly during that time, finally surpassing Goettingen in the latter nineteenth century. It was not until the twentieth century, however, that an American library (Harvard) surpassed in size the largest German library. ${ }^{6}$

Though the Goettingen library was, in many ways, the model for the other German universities, it was not imitated in one important factor-the strong librarian/selector-perhaps because librarians of Heyne's stature are always rare. In any case, though the goal was the same -strong, research-oriented collections, inclusive in scope and current in content -the means of obtaining them were usually different. Detailed regulations or directives were issued by the university administration governing the library in its activities, in most cases charging library faculty committees or commissions with the task of selecting library materials. ${ }^{7}$

These regulations were quite often so detailed that even the ratios by which the book funds were to be distributed between the various departments and faculties were spelled out. For example, at the University of Rostock, the book funds were split among twenty-one different departments. ${ }^{8}$

This then was the prevailing pattern of library organization in Germany in the years immediately preceding and during the beginning of the rapid growth of American universities. As a result-

American institutions founded before 1900

5 Ibid., p. 17.

I Ibid., p. 20.

T' Ibid., p. 26.

8 Ibid., p. 28. 
generally developed the practice of allocating most of their book funds and generally relied upon faculty and faculty committees to a greater or lesser extent. ${ }^{9}$

The pattern for this country was therefore set.

It is interesting to note that very shortly after the emergence of American universities and their libraries, a reaction against the faculty-developed collection set in across Germany. A rather formal system of subject bibliographers was adopted, and by 1900 virtually all German academic libraries had switched to this type of selection arrangement. Library bibliographers are still the prime selection agents in German academic main libraries, though the situation there is far from perfect. Each university, through its dozens of institutes and seminars, has developed literally scores of faculty-selected, non-circulating collections, each completely independent of the others as well as of the main library, and lacking such basic bibliographic adjuncts as a central author catalog. In most cases the book funds available to these small splinter collections total more than the main library's book fund. ${ }^{10}$

In American academic libraries today the traditional method of book selection is to allocate a sizable portion of the book fund to the various schools and departments, the faculties of which are primarily responsible for the selection of subject collections-the German system of approximately eighty-five years ago, with the difference that the responsibility for the collection administratively and legally may, and frequently does, reside in the library. ${ }^{11}$

Again, unlike the earlier German model, though selection is often a faculty responsibility, there has been an almost universal trend to library staff ad-

${ }^{9}$ Ibid., p. 30.

${ }^{10}$ Ibid., p. 47.

${ }^{11}$ Ibid., p. 34. ministration of book funds, accompanied by centralized ordering and cataloging. ${ }^{12}$ This viewpoint has been stated and restated over the decades by various librarians. In 1937 P. B. McCrum wrote-

... the faculty then is the extensive agent in book selection as the librarian is its intensive organizer. As such the librarian owes his faculty all possible deference in the matter of their special knowledge of books. He owes himself the pleasure of providing for their needs as generously as possible and as efficiently, and he owes it to the library to make for a rounded collection, adequate as a whole, not in spurts from hit and miss buying. ${ }^{13}$

\section{In 1954 N. F. McKeon wrote-}

... as collaborators with the library they (those devoted members who have a natural interest impelling them) select the books to be acquired in the subject concerned in the curriculum. . . . It is not too much to say that a college library is as good as the faculty it serves. ${ }^{14}$

In 1963 Guy Lyle presented the "traditional" view most elegantly in his book, The President, the Professor and the College Library.

Good libraries are the result of careful dayby-day selection in response to the express needs of departments. No single individual should be allowed to exercise undue control over the activities connected with building the library collections. Whenever a department head or individual professor dominates the selection and acquisition process, there is inevitably a disinclination on the part of other faculty members to participate fully.

The librarian has a job of leadership, but he should use his office to coordinate and inform and not to dominate book se-

\footnotetext{
12 Ibid., p. 58.

${ }^{13}$ Blanche P. McCrum, An Estimate of Standards for a College Library (Lexington, Va.: Journalism Laboratory, Washington \& Lee University, 1937), p. 104.

${ }_{14}$ Newton F. McKeon, "The Nature of The College Library Book Collection," in Herman H. Fussler, ed., The Function of the Library in the Modern College (Chicago: University of Chicago Press, 1954), p. 51.
} 
lection. If occasionally he becomes impatient with what appears to be the procrastinating and slipshod methods of his teaching colleagues he should not compound their faults by taking over their selection responsibilities.

For a more positive approach to the development of . . . book collections it is obvious that there must be a working combination of administrators, faculty and the library staff. Each has his role to play and the librarian cannot delegate his part. Despite his occupation with budgets, building, and staffing, the college librarian must make the development of the book collections his major concern. It is a task in which he should receive help from the faculty and the members of the administration and the library staff but for which he must assume the ultimate responsibility. To promote this "working combination" there are certain components which a college will be compelled to incorporate into its library program. Among these are: 1.) A clear understanding of what kind of library the college is supposed to be building and for what kinds of users. 2.) A genuine and general awareness of "the different roles which different books play."

3.) An effective organization for involving the faculty and library staff in book selection. 4.) A liberal and assured annual fund with regular annual increases for book purchases.

The librarian is concerned with the book development program as a whole as well as with his specific responsibilities in selection. He will see that policies and procedures for selecting and recommending each of the various types of books-reference works, standard works, general books and special collections-are clearly formulated and made known to the faculty. He will have the final responsibility for book purchasing and this will include the right to approve or disapprove book orders which seem grossly out of line with library policy. The faculty has a two-fold responsibility in building up library resources in a subject field. The first is to keep the collection up-to-date by a careful selection of new publications and a weeding of the old. The second is to fill gaps in the collection.
... The library staff's contribution to developing the library collection is made chiefly in the realm of general and reference books. ${ }^{15}$

In 1964 in the second edition of their textbook on book selection Mary Duncan Carter and Wallace Bonk wrote:

The various departments of schools and colleges are theoretically responsible for selection in their subject areas while the library staff remains responsible for the fields of general bibliography, for those areas not covered by departments, for special material such as periodicals and documents, and for overseeing the general development of the collection. ${ }^{16}$

A similar but more strongly worded statement appears in the May 1966 issue of $C R L$ :

Obviously, working closely with individual faculty members (in book selection) requires considerable time and patience from the librarian but the results prove well worth the effort. There is no gainsaying the fact that the only strong research collections with national quality are those built in depth by faculty and librarians working together as colleagues. ${ }^{17}$

In summary, this point of view maintains that since faculty members know their fields well, it should be their duty to select the important books in those fields for the library.

Over the past few years a counter tendency has shown itself in the literature. This viewpoint suggests that librarians should take more initiative in collection development and the faculty less. In effect these authors would have American academic libraries, at least the larger ones, move closer to the position of the German university main library.

15 Guy Lyle, The President, The Professor, and the College Library (New York: H. W. Wilson, 1963), p. 37-47.

16 Mary Duncan Carter and Wallace Bonk, Building Library Collections (2d. ed.; New York: Scarecrow, 1964 ), p. 87-8.

${ }^{17}$ Jack A. Clarke, and Richard M. Cooklock, "Book Selection; From Teacher's College to University," $C R L$, XXVII (May 1966), 224. 
As early as 1934 William M. Randall wrote as follows:

This practice [the departmental allocation of book funds] although it seems theoretically to be sound has two disadvantages. In the first place, when the comparatively small gross book budget is divided between from 15 to 30 departments, the amounts assigned to each are small. ... The second disadvantage $\ldots$ is the failure to secure certain outstanding works in the various fields because the department head who passes upon book purchases sees no immediate need for them.

Thus, usually, control of the greater part of the funds for book purchases passes from the library to the department head. Yet the primary responsibility of the librarian in a college is to maintain balance in the collection and to make sure that future as well as present needs are filled. ... One possible escape from the difficulty is for the college to refrain from a departmental budgeting of its book funds and instead to leave them, or a large portion of them, in one sum under the control of the library. ... It is certainly evident that some means must be found to correct the ordinary attitude of the faculty toward the library. . . . Too much influence is given at present to the individual tendencies of single members of the faculties. The result has been poorly balanced book collections with some subjects overdeveloped and some almost neglected.

The routine of [acquisition by] purchase is comparatively standardized throughout the group of colleges [studied-205]. The initiating of the purchase ordinarily comes from the faculty, who indicate to the librarian the titles to be acquired on their individual budgets. In many colleges, no check is made of this list, . . . and books asked for by the faculty members are purchased so long as funds are available. Such a procedure is responsible ... for the lack of balance everywhere evident in college library collections.

The evident remedy for this would seem to consist first, in having a librarian capable of choosing books in the light of the aims of the college and with an eye to the development of its book collection as a unit and second, in giving to such a librarian wide power in the initiating of purchases from departmental funds. . . . What the average college library appears to need more than any other one thing is a directing head capable of unifying its aims and translating them into books. ${ }^{18}$

In 1940 Keyes Metcalf wrote a chapter for a book edited by Randall:

I have already stated my belief that too much reliance on faculty initiative has been unfortunate, I might also say disastrous. What then can be done? It seems to me evident that the solution should be two-fold. 1. While we should not expect faculty to do the work without aid or compulsion, full benefit of the special knowledge residing with its members should be taken advantage of and every effort made to persuade its members to suggest freely titles for purchase and also to cover systematically the fields in which they work. 2. I believe that at least in a large institution the subjects which the library tries to cover should be divided between members of the library staff. In these libraries it should be possible to find men and women who have a fair, even if somewhat simplified, knowledge of most of the broad fields. These assistants may do very little of the book selection themselves, but they should have the responsibility of seeing that there are called to the attention of the faculty members who are specialists the various lists of new books and old books that are available and that these specialists shall be almost forced to make recommendations. The staff members should then try to cover material that falls between the different lines cared for by the faculty and thus round out the work. ${ }^{19}$

In Guy Lyle's The Administration of the College Library, Paul Bixler, librarian of Antioch College, writes in the

\footnotetext{
18 William M. Randall, The College Library (Chicago: ALA, 1932), p. 22-23, 105-107.

${ }^{10}$ Keyes Metcalf, "The Essentials of an Acquisitions Program," in William M. Randall, ed., The Acquisition and Cataloging of Books (Chicago: University of Chicago Press, [c. 1940]), p. 82-83.
} 
chapter on "Book Selection and Acquisition":

There seems to be a good deal of haphazardness about the way in which most college library book collections are built up. The faculty initiate most of the orders in the special fields of their several departments of instruction. The librarian and library staff order as a matter of course many books of obvious importance which are not definitely in departmental fields. ... Where there is plenty of money and bibliographical enthusiasm selection need follow no plan. ${ }^{20}$

\section{In 1963 S. A. Stiffler states:}

From a statistical point of view, the major problem in acquisition policy for smaller institutions with limited financial resources is that of selection from a constantly increasing rate of publication. . . . What should the librarian's responsibility be in supervising the quantitative and qualitative growth of his book collection? Some librarians appear to follow ... a simple stimulus-response buying policy. Especially is this so if general funds are limited and if the budget is departmentally allocated. This policy, insofar as it is a decision (or an implicit acquiescence) of the librarian represents too often failure to discharge the full measure of his professional responsibility. ${ }^{21}$

Again in 1963 the University of Illinois published eleven papers resulting from a Graduate School of Library Science institute held at Allerton Park on "Selection And Acquisition Procedures Of Medium-Sized And Larger Libraries." The first, by Robert Downs, has a bearing on this study. He writes:

It is a fairly common practice in college and university libraries for the staff to abdicate responsibility to the faculty for book

${ }^{20}$ Paul Bixler, "Book Selection and Acquisition," in Guy Lyle, The Administration of the College Library (2d ed., rev.; New York, H. W. Wilson, 1949), p. 348.

${ }^{21}$ S. A. Stiffler, "A Philosophy of Book Selection for Smaller Academic Libraries," CRL, XXIV (May 1963), 204. selection. . . We shall be able to rely in the future even less than in the past on the faculty for aid in book selection because academic careers are being built increasingly, not simply upon teaching, but upon research and publication.

Every large library has or should have subject specialists in its organization, and others can be trained to assist in selection processes. In brief, these [bibliographical skills] are competencies that can be acquired by intelligent professional librarians who may lack extensive formal training or subject specialties. ${ }^{22}$

Another pertinent paper in this volume was contributed by Robert Orr of Iowa State University. He writes:

It seems to me that the sooner such cumbersome and sometimes troublesome methods of administering library funds [departmental allocations] are eliminated in favor of centrally administered library funds the better off all concerned will be. Moreover, in my opinion, there is a greater likelihood then of achieving a more balanced development of the book collection as a whole where funds are centrally administered. ${ }^{23}$

Many other papers, by such people as W. R. Pullen, ${ }^{24}$ Maurice Tauber, ${ }^{25}$ James Skipper, ${ }^{26}$ and R. A. Miller, ${ }^{27}$ have stated ideas and principles similar to the above.

One of the most recent statements is

22 Robert Downs, "The Implementation of Book Selection Policy in University and Research Libraries," in Selection and Acquisition Procedures In MediumSized and Large Libraries (Allerton Park Institute Papers No. 9), Urbana; University of Illinois, Graduate School of Library Science, 1963, p. 4-8.

${ }^{23}$ Robert Orr, "The Selection, Ordering and Handling of Serials," Ibid., p. 74.

${ }^{24}$ W. R. Pullen, "Selective Acquisitions at Yale," in Studies In Library Administrative Problems: Eight Reports From A Seminar In Library Administration Directed by Keyes D. Metcalf (New Brunswick: Rutgers-The State University, Graduate School of Library Service, 1960), p. 23-40.

${ }^{25}$ Maurice Tauber, "Faculty and the Development of Library Collections." Journal of Higher Education, XXXII (November 1961), 454.

${ }^{26}$ James E. Skipper, "The Continuing Program of Book Selection and Acquisitions," Library Resources \& Technical Services, II (Fall 1958), 265.

${ }^{27}$ R. A. Miller, "A Look In The Mirror-25 years of Librarianship," Library Journal, LXXXVII (October 1,1962$), 3379$. 
by Robert Haro of the University of California, Davis, ${ }^{28}$ who reported on a survey he made of acquisition practices of seventy academic libraries in the range three hundred thousand to a millionplus volumes. Sixty-seven of those queried replied, and of these the library staff of sixty-two were engaged to a greater or lesser extent in book selection. Selection, for the purpose of his report, "excludes the selection and purchase of reference materials and occasional general items for the library." He states that

... . while most academic librarians now agree that they [librarians] should engage in book selection, there is at present little agreement on selection methods and procedures. . . . Most of the larger academic libraries with firmly established area studies or medium sized libraries with accelerated programs for collection development were utilizing bibliographers or subject specialists responsible for the selection of library materials.

The statistical tables accompanying his article are of some interest.

Charles Burdick, associate professor of history, San Jose State College, wrote an article in 1964 that also pertains to this subject. ${ }^{29}$ In it he speaks out against the domination of book selection by faculty and proposes the use of library subject bibliographers:

The responsibility for expanding the holdings is divided among 25 to 30 souls, some interested, others oblivious, and a minority intellectually dead. They order whatever happens to strike their fancy, what they selfishly desire for their personal esoteric projects, and what they find reviewed in current journals. These members of the faculty have little comprehension of the overall collection. They are current but no more. They are further limited by the research field of competence from which

\footnotetext{
${ }^{23}$ Robert Haro, "Book Selection in Academic Libraries," CRL, XXVIII (March, 1967), 104.

${ }^{29}$ Charles Burdick, "The Library and the Academic Community," Library Resources \& Technical Services, VIII (Spring 1964), 159.
}

they seldom emerge. The product is uneven, questionable on every hand except quantity and of dubious value to future generations.

This is a strong statement, to say the least, but as it originated with a faculty member and not a librarian, it seems peculiarly pertinent here.

Another statistical survey was done by C. James Schmidt, associate librarian of Southwest Texas State College. He surveyed the twenty-one other Texas state institutions of higher education and presented the results in an article. Referring to Harry Bach's 1951 article in $C R L$, he assumed that

whether the library staff or the faculty has the primary responsibility for selecting materials seems to hinge on whether or not the [book] budget is allocated to instructional units. ${ }^{30}$

Twenty institutions replied to his inquiry, and eighteen indicated they did allocate their budget. At twelve of these, the faculty library committee was involved in the allocation of funds. The majority, twelve of the twenty, allocated from 40 per cent to 60 per cent of the total book funds, but only three of the twenty had formal collection or selection policies.

In $1963 \mathrm{~J}$. H. Richards wrote an article for Library Trends on "Academic Budgets and Their Administration." 31 It was based on a questionnaire study of more than one hundred "better known" colleges and universities; ninety-five replied. Of these, all but seventeen allocated book funds. Among the seventyeight that did allocate, eighteen used an allocation formula. In only four institutions were the allocations of the book fund made by the faculty library committee.

${ }^{30} \mathrm{C}$. James Schmidt, "Administering the Book Budget: A Survey of State Supported Academic Libraries in Texas," Texas Library Journal, XLII (Summer 1966), 51.

31 James H. Richards, Jr., "Academic Budgets and Their Administration," Library Trends, XI (April $1963), 420$. 
Another aspect of collection development that occupies the attention of many people writing on the question of selection is that of selection policy statements. No one wrote against a selection policy; if mentioned, it is praised. In fact, the October 1953 issue of $C R L$ had a "symposium" on the subject of acquisition policies in which can be found articles by Robert Vosper, Eileen Thornton, and Herman Fussler-all in favor of acquisition policy statements.

In 1954 Felix Reichmann questioned thirty-one university libraries on the subject of acquisition policy statements. Seven replied that they had formal written statements, while twenty stated that they had formulated, though unwritten, policies. ${ }^{32}$

Clarence Gorchels studied this problem as it applied to colleges of education. Of eighty-six schools queried, sixty-five did not have written statements. Twenty reported they did have statements, but of these three were really statements of ordering mechanics, and seven were very short-a few brief statements of generalities; five libraries had rather complete one-page statements, and five had long (two to eight pages) complex statements. One reply was incomplete and therefore not summarized..$^{33}$

Is there a trend to be seen in the study of the literature of library selection processes? The answer would seem to be "yes," and the initial choice of terms to describe the two major approaches to selection-(1) faculty-"traditional," and (2) library staff-"modern"-shows the direction of the trend. As the above quotations may have shown, the bulk of the writing on this subject seems to be more and more in favor of library staff selection, at least

32 Felix Reichman, "Current Acquisition Trends in American Libraries," Library Trends, III (April 1955), 462.

${ }^{33}$ Clarence Gorchels, "Acquisition Policy Statements in Colleges of Education," Library Resources \& Technical Services, V (Spring 1961), 157. for the majority of library items and within the framework of larger academic libraries.

Accompanying this trend is the frequently stated need to add qualified subject specialists to the staff; Cecil Byrd writes on this subject as it pertains to the Indiana University library, where ten professional subject specialists were added to the staff in the three years 1963 through 1966. ${ }^{34}$ Another development, often noted, is the requirement to write a workable "selection" or "collecting" policy statement.

Danton sees a trend developing toward increased library selection. $\mathrm{He}$ quotes surveys from the late 1920's and early 1930's which show almost all book selection being done by the faculty. ${ }^{35} \mathrm{He}$ says that today, however, (writing in 1962 ) there exist libraries "among them some of the largest and best-in which a clearly recognized joint responsibility exists and in which members of the library staff actually perform a great deal of book selection." 36

What then might be future developments in this field? On this subject the literature in general is vague. There is a tendency, quoted above, to use more subject bibliographers on the staff of the larger academic libraries. In smaller institutions, the courses of action that seem to be most frequently suggested are the writing of a selection policy, a closer library coordination of the book selection and collection development activities, and intelligent faculty-library staff cooperation. For example, the new Canadian university library standards state:

Book selection should be the joint responsibility of the teaching staff and the library staff. The teaching staff should be consulted about the books needed for the present and future teaching programs ... within the defined policy for the collection

\footnotetext{
${ }^{34}$ Cecil K. Bvrd, "Subject Specialists in a University Library," CRL, XXVII (May 1966), 191.

${ }^{35}$ Danton, op. cit., p. 62-63.

${ }^{36}$ Ibid., p. 63.
} 
all library staff members should suggest purchases. ${ }^{37}$

The Waples-Lasswell study, though now thirty years old, is often quoted to show that librarians can build a better collection than can teaching faculty. In this study nearly five hundred books written in English, French, and German on the social sciences were selected as "important" by a group of specialists in the field. These books were then checked against various libraries. The result shows that the Harvard library contained 63 per cent of the volumes, University of Chicago library held 49 per cent, California at Berkeley held 40 per cent, University of Michigan library had 31 per cent. These were basically faculty-selected collections. On the other hand, the New York public library, assembled by librarians and subject bibliographers, held 92 per cent of the total. ${ }^{38}$ It would be interesting to repeat this experiment today-perhaps in some field in addition to, or in place of, the social sciences.

Again, as on the history of the development of the library acquisition processes, Danton is the most detailed and far ranging in his discussion of the weaknesses of the current position and in suggesting future courses of action. In his 1963 book he lists seven flaws resulting from too great dependency on faculty selection. Among these the more serious are the resulting imbalance of the collection, the reduction of flexibility of acquisition programing, and neglect of peripheral and overlapping subject areas. ${ }^{39}$

Danton sums up his position as follows-

... the evidence and position of this study are not in opposition to faculty participa-

\footnotetext{
${ }^{37}$ Canarian Library Association, Report of the University Library Standards Committee, 1961-1964: Guide to Canadian University Library Standards, (rOttawa]: Canadian Library Association, 1965), p. 19.

${ }^{38}$ Douglas Waples and Harold Lasswell, National Libraries and Foreign Scholarship (Chicago: University of Chicago Press, [c. 1936]), p. 71.

${ }^{3}$ Danton, op. cit., p. 69-70.
}

tion-to the fullest-in . . . book selection in all its aspects. Quite the contrary. The evidence is rather against the faculty's ultimate authority and responsibility, against the largely unrestricted allocation of funds to the faculty, against too great reliance on the faculty of the library, and against the uncoordinated collection building, inadvertent inbalances, and other disadvantages which result to scholarship from these practices. ${ }^{40}$

As for recommendations for the future development of collection building practices, Danton, in a lengthy article published in 1967, says:

In view of the facts and observations described ...., it seems possible to offer the following suggestions and conclusions: Most Anglo American University Libraries and those operating similarly should move as speedily as possible toward a comprehensive plan of book selection by library staff specialists. Such a plan should in no sense inhibit or prevent able and willing members of the faculty from selecting books in their fields but would rather a) insure that the important books in all relevant fields are acquired, b) place authority where responsibility now generally exists (i.e. the library) and c) place book selection subject to library administrative control and supervision. ${ }^{41}$

Harry Bach concludes his 1957 article as follows:

It is the writer's conviction that the librarian ought to assume responsibility for the development of the library collection. If a librarian fails to act the part of a librarian, what is he? He is a custodian of books, a glorified research assistant, a business manager at the most. . . . Librarians ought to consult with the faculty, librarians ought to take advantage of the special advice that is available to them, but librarians ought not to depend on the faculty to do three jobs-teach, do research and develop library collections. It is unfair to the faculty and it is unfair to the library. ${ }^{42}$

\footnotetext{
40 Ibid., p. 82.

41 J. Periam Danton, "The Subject Specialist in National and University Libraries With Special Reference to Book Selection," Libri, XVII (1967), 55.

${ }^{42}$ Bach, op. cit., p. 450.
} 